VIABILITY OF REMANUFACTURING PRACTICE: A STRATEGIC DECISION

MAKING FRAMEWORK FOR CHINESE AUTO-PARTS COMPANIES

\author{
Muhammad Dan-Asabe Abdulrahman \\ Nottingham University Business School China, \\ The University of Nottingham Ningbo China, \\ 199 Taikang East Road, Ningbo, 315100. \\ muhammad.abdulrahman@nottingham.edu.cn \\ Phone: +8657488180019 \\ Nachiappan Subramanian* \\ Nottingham University Business School China, \\ The University of Nottingham Ningbo China, \\ 199 Taikang East Road, Ningbo, 315100. \\ nachiappan.subramanian@nottingham.edu.cn \\ Phone: +8657488180197 \\ Chang Liu \\ School of Economics \\ The University of Nottingham Ningbo China, \\ 199 Taikang East Road, Ningbo, 315100. \\ Chang.liu@nottingham.edu.cn \\ Shu Chengqi \\ Nottingham University Business School China, \\ The University of Nottingham Ningbo China, \\ 199 Taikang East Road, Ningbo, 315100. \\ zy04030@nottingham.edu.cn \\ * Corresponding Author
}




\title{
VIABILITY OF REMANUFACTURING PRACTICE：A STRATEGIC DECISION MAKING FRAMEWORK FOR CHINESE AUTO-PARTS COMPANIES
}

\begin{abstract}
Remanufacturing is a sustainable and proven profitable practice in the western world. Research on remanufacturing practices is relatively unexploited in China, despite being the "global factory" and both the world's largest automobile manufacturer and vehicle market. The increasing amount of automotive output and End-of-Life vehicles (ELVs) in China provides Chinese auto-parts companies with significant potential for environmentally conscious manufacturing and product recovery. Using case studies, we have investigated the status of remanufacturing practices, key determinants for strategic decision making to remanufacture in-house, outsource remanufacturing and/or not to engage in remanufacturing in Chinese auto parts firms using an analytical hierarchy process (AHP). This study suggests that Chinese firms are keen to adopt remanufacturing practice in-house compared to outsourcing despite a lack of technical and managerial capabilities.
\end{abstract}

Key words: Remanufacturing, automotive, China, strategic decision making, analytical hierarchy process (AHP)

\section{INTRODUCTION}

The unprecedented and sometimes wasteful use of the environment as the natural provider of resources and sink for discarded end-of-life/end-of-use products and waste is proving to be unsustainable. There is increasing realization that manufacturing needs to produce more with less and different raw materials, to be ethical and sustainable. Achieving this will require materials wastage to be reduced and production to more closely match demand. This is why manufacturing firms, especially original equipment manufacturers (OEMs) and their suppliers, are under increasing pressure from stakeholders, including regulators, customers and employees to produce ethically, reuse/recycle, remanufacture, and/or to safely discard 
their waste in accordance with the absorptive and regenerative capacity of the planet (Barker and Zabinsky, 2011).

Of the many sustainable strategies, tools and techniques developed over the years aimed at improving productivity and economic longevity of manufacturing businesses, remanufacturing plays an important role. Remanufacturing has resulted in increased profits and market share for manufacturers in Western countries (Jayaraman and Luo, 2007; Giannetti, 2012). Remanufacturing further benefits businesses in terms of cost saving from reduced resource requirements, through assets recovery and reusing/recycling, cost savings from not using landfills, expanded product life cycle, increased employment rate and improved brand image (Sarkis, 2010; Kapetanopoulou and Tagaras, 2011; Zhang, et al., 2011).

The automotive industry is one of the leading industries in remanufacturing and product recovery strategy, with $70 \%$ of all remanufacturing companies being in the automotive sector (Steinhilper, 2011; Zhang, et al., 2011). Furthermore, of all major products that are being remanufactured, automotive components remanufacturing is the most prevalent (Steinhilper, 2011).

The United States is reported to be the headquarters for many of the world's leading automotive parts remanufacturers, with an estimated remanufactured automotive parts sales of US\$553 billion in 2011(USITC, 2012). Volkswagen, for example, has engaged in remanufacturing since 1947, and its remanufactured original engines alone have reached 7.48 million units so far (Zhang, et al., 2011). The above examples demonstrate the tremendous 
economic opportunities offered by remanufacturing in the automotive industry, especially in the auto-parts sector.

Driven by regulatory forces in Europe and profitability in North America, remanufacturing automotive parts has traditionally prospered in those parts of the world (Chapman, 2010; Srivastava and Srivastava, 2006). What is most striking, however, is how remanufacturing is relatively unexploited in China, despite China being the "global manufacturing factory" and the world's largest automobile producer and market (Amighini, 2012; PwC, 2011). Virtually all attention and research into remanufacturing over the past decade has been concentrated in developed Western countries with relatively little attention being devoted to developing nations such as China and India. With China's estimated 55 million in-use vehicles and 4.8 million ELVs in 2010 alone, coupled with over 356 officially approved ELV dismantlers and more than 800 take-back stations that employ over 16,000 people (Chen and Zhang, 2009), the dearth of information on remanufacturing in China needs addressing.

The major motivation for this study is to (i) develop a remanufacturing decision-making framework for the Chinese auto-parts manufacturers' strategic decisions to either engage in the remanufacturing practice in-house, outsource or to not engage in remanufacturing and (ii) to investigate the critical factors affecting remanufacturing practices in the Chinese auto-parts industry.

The remainder of the paper is organized as follows: the significance of remanufacturing is reviewed through literature in section 2 , a comprehensive discussion on the strategic issues governing remanufacturing decisions is discussed comprehensively in section 3 , in section 4 the methodology employed for this study is provided, results of the study are reported in 
section 5, and discussions are narrated in section 6 . Finally the paper concludes with the summary and future scope of research.

\section{REMANUFACTURING LITERATURE REVIEW}

Remanufacturing has no universally accepted definition (Chapman, et al., 2010; Hauser and Lund, 2008; Bras and Mcintosh,1999). For example, Chapman, et al., (2010) define remanufacturing as "an industrial process of returning a used product to at least its original performance, equivalent to or better than that of the newly manufactured product." Hauser and Lund (2008), however, state that: "Remanufacturing is the process of transforming durable products that are worn, defective, or discarded to a 'like new or better' condition through a production-batch process of disassembly, cleaning, refurbishment and replacement of parts, reassembly, and testing." Following this definition, Ijomah (2009) further suggests that "the performance specification should be returned to the original level from the customers' perspective and warranty will be given as equivalent to new products". These definitions are essentially of the same idea, which is the restoration of used or end-of-life products, modules or parts to like-new condition in a manufacturing environment. The contentious issue with definitions of remanufacturing stems from the expected quality and performance level of a remanufactured product compared to a newly manufactured product.

Differences in definitions notwithstanding, it is worth noting that remanufacturing is different from repairing, reconditioning and recycling. Repairing and reconditioning only restores failed products or components to 'working order', with the repaired or reconditioned product generally regarded as inferior to the original mode. Recycling on the other hand deals with the recovery and reuse of materials from end-of-life products. The recovered material acts as raw material in the manufacturing of products with possibly different functions from the 
original. In other words, recycling denotes material recovery without preserving product structures; for instance, metal recycled from scrap vehicles. However, by recycling at the components core or higher level rather than the raw material level, remanufacturing maintains the products' original function, and preserves the value-addition of the material contents of the product. Furthermore, the reverse supply chain of recycling is an open-loop while in the case of remanufacturing it is a closed-loop. Remanufacturing is therefore regarded as the ultimate form of recycling, as it not only preserves the identity of the original product but also gains value additions during the remanufacturing process which helps to extend life span, increase product reliability and improve ease of maintenance (Junior and Filho, 2011).

\section{------INSERT TABLE 1 ABOUT HERE------}

Despite the demonstrated economic, social and environmental benefits of remanufacturing, however, few OEMs are engaged in remanufacturing with only $6 \%$ of over 2000 remanufacturing firms studied in the United States found to be OEMs (Hauser and Lund, 2008). It is mostly third-party independent operators that are found to be more aggressively engaged in the remanufacturing of products they did not design (Chen and Chang, 2012). Past studies have examined the issues, motivations or factors, and decision making models affecting remanufacturing and related reverse logistics (Rahman and Subramanian, 2011; Subramoniam et al., 2013). Early notable works on the important issues affecting remanufacturing came from Kutta and Lund in 1978, in which they highlighted factors such as trends towards mass customization of products, the complex nature of replacement parts, and uncertainty of time, and the quality and quantity of returned products (Kutta and Lund, 1978). Hammond et al. (1998) tried to verify these proposed factors by conducting surveys to 
understand which factors are relevant, and the relative priority of each. In the section that follows, we present a strategic remanufacturing decision-making framework based upon a comprehensive review of the key issues governing remanufacturing practices. We consider this remanufacturing framework to be comprehensive since it incorporates all key business aspects such as technical, market, economic, regulatory, environment and managerial aspects. These are the critical issues that take care of feasibility of remanufacturing based on new product development, environmental protection and managerial support. Therefore managers should fully understand and to ensure that they have the capability and/or means of overcoming each before engaging their firms in the complex process of remanufacturing (Kutta and Lund, 1978; Hammond et al., 1998; Rahman and Subramanian, 2011; Subramoniam et al., 2013).

\section{STRATEGIC REMANUFACTURING DECISION FRAMEWORK}

In traditional new product design, after the conception of a new idea, a company would typically evaluate the design based on three aspects: technical, market and economic issues before manufacturing. In the case of remanufacturing, however, in addition to the above, companies would try to take into account additional issues such as regulatory, environmental and managerial aspects of the planned product. Hence our strategic framework has technical, market, economic, regulatory, environmental and management as its key factors. We have summarized a few strategic factors influencing remanufacturing decisions as per our strategic framework in Western perspectives in Table 2. In total, 14 sub-factors are broadly classified into 5 major factors: technical (the capacity to provide remanufactured products), market (concerned with the marketing of the recovered and remanufactured product in the secondary market), regulatory and environmental, financial, and management support. 


\subsection{Technical}

Technical issues in remanufacturing are complicated and require significant modifications to traditional production planning and control systems (Guide, 2000). The production planning and control systems in remanufacturing needs to be capable of managing wide-ranging objectives associated with diverse returned product conditions, and to closely coordinate the activities of sorting, disassembly and reassembly of remanufactured products (Guide, 2000). Guide (2000) listed seven major characteristics of remanufacturing that seriously complicate the system to include: (1) the uncertainty in timing and quantity of returns, (2) the need to balance returns with demands, (3) the disassembly of returned items, (4) the uncertainty in materials recovered from returned items, (5) the need for a reverse logistics networks, (6) the complication of material matching requirement, and (7) the routing and processing time uncertainty. Other characteristics include: planning, execution and control of remanufacturing operations (Flapper et al., 2002). Most of these remanufacturing issues can be broadly grouped into two major categories: availability of timely and high-quality cores (reverse logistics), and the remanufacturability of the cores (design, part matching and recoverability).

The availability of a robust reverse supply chain is critical in supporting good cores availability that is the backbone of remanufacturing and the decision to remanufacture (Rahman, Subramanian, 2011). However, the lack of specific remanufacturing logistics technologies and techniques coupled with other factors such as the number and location of take-back centers, product return incentives, transportation methods and decisions on whether to own or outsource reverse logistics channels all complicate remanufacturing (Hammond et al., 1998). The use of material-requirement-planning (MRP) logistics for addressing the 
uncertainty in the supply of used parts and demand for remanufactured products has been proposed to overcome some of these issues (Ferrer and Whybark, 2001).

The design, part match and recoverability of a product/component also affect its remanufacturability. Product design influences the disassembly and is regarded as the most important process in gaining reusability and remanufacturability (Hammond et al., 1998; Wu, 2013). By including the needs of post-use collection in product design, efficient remanufacturing could be achieved (Bellmann and Khare, 2000). Similarly, 'Parts Proliferation' - the practice of making many variations of the same product with one or two minor differences, increasing the diversity of products, uncertainty in the material recovered and a lack of cross referencing for aftermarket suppliers' parts, all add to remanufacturing difficulty, as these create high pressure on scheduling and information systems (Guide et al., 1999).

\subsection{Management}

Every organization is a reflection of its top management teams (Hambrick, 2007). Heterogeneity within top management teams in terms of education, function and tenure has a positive relationship with corporate performance and level of innovation (Carpenter, 2002). A firm with a passive management attitude will only implement remanufacturing and other sustainability practices under external or internal pressures which are difficult to avoid (Rogers and Tibben-Lembke, 1999).

The availability of a skilled workforce is another critical aspect as remanufacturing is inherently labor intensive due to the heterogeneity of inputs requiring small lots in the production process with no automated techniques for sorting, grading and disassembly 
(Guide and Van Wassenhove, 2001). The lack of expertise and skilled workforce with the requisite knowhow is a predominant barrier in the inspection, refurbishing and reassembly process and a major reason for firms electing not to undertake remanufacturing activities (Mukherjee and Mondal, 2009; Kapetanopoulou and Tagaras, 2011).

Furthermore, there is the need for organizational integration that takes suppliers, consumers, as well as internal alignment between original equipment (OE) and aftermarket divisions into consideration. Organizational integration with both suppliers and customers is known to be positively related to performance, with greater willingness to return products when OEMs collect and remanufacture their own products (Michaud and Llerena, 2006).

\subsection{Financial}

A key barrier to remanufacturing implementation is the need for upfront investment which involves high initial setup costs for new facilities and recruitment (Sandvall and Stelin, 2006; Subramoniam et al., 2013). The financial burden is even heavier if it is established in a less developed market where companies have to deal with the core availability issues themselves, and where a 'swing system' of used components for new components may need to be introduced (Sandvall and Stelin, 2006). In this way, however, the manufacturer must invest in the selling of new components marked as 'remanufactured', thus making a loss due to different prices between a remanufactured and a new component. Also, the upfront investment may take a long time to be written-off (Subramoniam et al., 2013).

However, the profitability of remanufactured products has been the main driver for its implementation (Hauser and Lund, 2008; Chen and Chang, 2012). Generally, the reduced cost of raw materials, energy, manufacturing plants and equipment, extended product life 
cycles, a larger customer base resulting from reduced prices in addition to reduced liability for waste management can all be sources of profitability (Hauser and Lund, 2008). An estimated material saving of $70 \%$ and cost saving of $40-60 \%$ compared to brand new products was found with only $20 \%$ of the effort needed in remanufacturing (Hauser and Lund, 2008; Chen and Chang, 2012). Indeed, the high expectation on potential profitability was the main driver of remanufacturing by pioneers like Ford and BMW (Toffel, 2004). Other incentives for remanufacturing implementation include government tax reductions and subsidies (Mitra and Webster, 2008). Subsidies compensate for the cost of assessing, dissembling, matching and reassembling processes and also offset the initial cost of emergent technologies which are high during the initial period but less significant once economies of scale are reached (Willis, 2010). Similarly, the reduction of VAT on a particular product or service is known to result in "an equivalent reduction in the price of that service" (Copenhagen economics, 2007).

\subsection{Regulatory}

Regulations provide incentives as well as barriers to the adoption and implementation of remanufacturing. On the one hand, environmental legislations, such as the Waste Electrical and Electronic Equipment (WEEE) directive in the EU, the End-of-Life Vehicles (ELV) takeback policies of Germany, the Universal Waste Rule (1995) of North America, Japan's Extended Producer Responsibility (EPR) law, amongst other similar legislations, are making take-back and recycling and remanufacturing a necessity for OEMs. This is especially due to growing penalties, fines, and legal costs of not complying with such regulations (Lai and Wong, 2012). On the other hand, the protection of intellectual property is a major barrier to remanufacturing and/or to the outsourcing of remanufacturing (Subramoniam et al., 2010; Guide and Van Wassenhove, 2001). OEMs' key IP concerns are, firstly, the risk of losing IP 
when outsourcing recycling and/or remanufacturing to a third-party service provider (Pagell, 2007); secondly, the on-going battle between companies, especially with their foreign competitors, over IP issues makes companies from developed countries less willing to invest or transfer specific know-how to firms in developing countries and regions perceived to have high IP risks. These two issues negatively impact on possible outsourcing of remanufacturing. Peng and Su (2011) recommend increasing remanufacturing patent license fees to alleviate IP concerns and protect the rights of patent holders. They further suggested that increasing remanufacturing patent license fees will result in an efficient allocation of excess profits from product remanufacturing in the supply chain.

\subsection{Market}

Since it is customers who demand and drive the development of green manufacturing, the 'green' image of remanufactured products can be an important marketing tool (Atasu et al., 2005). However, while a remanufactured product should be of the same or better quality (due to technical upgrading of the remanufactured product) compared with the original, consumers tend to regard remanufactured products as of lower quality and lower market price (Dowlatshahi, 2005; Kapetanopoulou and Tagaras, 2011). The poor quality image for remanufactured products from customers combined with OEMs' fear of market cannibalization - the potential for a remanufactured product drawing customers away from a new product by the same company and thereby eroding the sales of the new product - has been identified as the central issue in the continuing development of closed-loop supply chains (Guide and Li, 2010; Wu, 2013).

There is no fact-based evidence for market cannibalization with respect to remanufactured products (Guide and $\mathrm{Li}, 2010$ ). In fact, some argue that there is an entirely new segment of 
consumers who are not likely to purchase new products but remanufactured ones (Stock, et al., 2006; Jayaraman and Luo, 2007; Ferrer and Swaminathan, 2010; Giannetti, 2012). Despite the emergence of pro-remanufacturing customers, some OEMs engage in remanufacturing only when it provides them with a niche and competitive market opportunities (Atasu et al., 2005; Atasu et al., 2010; Wu, 2012). For example, Bosch Tools (USA) decides to remanufacture only if the market share is small and the new product guarantees a high price premium (Atasu et al., 2005; Atasu et al., 2010).

\section{METHODOLOGY}

A case study was carried out using qualitative data gathered from two leading Chinese autoparts companies to investigate aspects related to technical, management, market, financial, regulatory and environmental aspects of remanufacturing implementation decision.

The two companies selected for the study are leading Chinese auto-parts companies operating in Zhejiang Province. Contrary to Eisenhardt's (1998) recommendation of four to ten as the number of cases that a researcher should select, other scholars showed that a smaller number of cases provide greater opportunities for depth of observations (Narasimhan and Jayaram, 1998; Dyer and Wilkins, 1991; Voss et at., 2002). In fact, Dyer and Wilkins (1991) argued that single case studies enable the capturing of much greater detail of the context within which the phenomena under study occur. We selected these two major automotive components manufacturers based on their availability and willingness to participate and share the characteristics of their manufacturing/remanufacturing operations (Stuart et al., 2002). According to Stuart et al. (2002), case selection should be guided more by its potential to help and contribute to the research objectives rather than by concern for randomness. The two companies are prominent representatives of the auto parts industry, being amongst the largest automobile parts manufacturers in China. Importantly, the products of both companies belong 
to an established remanufacturing category (Steinhilper, 2011). Besides, because both companies are suppliers to global brands (see Table 3); they are more likely to be better aware of global best practices such as remanufacturing. Additionally, while both companies selected are medium-large sized companies, one of them is bigger than the other in size (facilities and global reach) and annual turnover (see Table 3). This variation in sampling is more likely to provide rich information on the phenomena (remanufacturing), being studied and to produce a really convincing account of what is being observed; additionally to have heterogeneous representation (Curtis S. et al., 2000; Miles and Huberman, 1994).

\subsection{Case companies' profile}

Respondents' and organizational characteristics of the industries chosen for our study are shown in Table 3.

Automotive Company A: The Company is a leading manufacturer of starter motors, alternators, brakes, water pumps, body structural parts, trims and decorative parts of passenger vehicles and other accessories for the automotive sector and is located in Zhejiang Province. The company started its operation in 1992 and is a joint venture wholly locally owned with nearly 20 years' of manufacturing experience. The company supplies global brands such as the Renault Nissan Alliance, Volkswagen AG, GM, and BMW with various auto-parts. It has about 11 dedicated supply chain management and reverse logistics management employees and annual revenue of 600 million dollars. The company is ISO $14000 / 18000$ standard certified.

Automotive Company B: The Company is a leading manufacturer of alternators, brakes, clutches, air conditioners, door panel series, stamping parts and tube auto-seating series, airconditioning control series, and other accessories for the automotive sector and is located in 
Zhejiang Province. The company started its business operation in 1986 and is a wholly locally owned private company with 26 years of manufacturing experience. The company supplies global brands such as GM, Ford, Toyota, DFAC, Faurecia, Valeo, and Bosch with the various auto components that it produces. It has about 15 dedicated supply chain management and reverse logistics management employees and annual revenue of 200 million dollars. The company is ISO / TS16949 / ISO14000 standard certified.

The respondents for both companies were selected primarily because of their direct involvement and knowledge of the subject area of this study. Additionally, the respondents are all top management level officers who are responsible for the determination of priorities in their respective companies and have a minimum of three (3) years' experience in the automotive industry in an executive/managerial capacity. We interviewed three of these key respondents in each company to minimize observer bias and to enable us to capture in greater details and depth the designed objectives of the study. Table 3 shows the company and the respondent profiles.

\section{----INSERT TABLE 3 ABOUT HERE -----}

\subsection{Data collection}

The data was gathered mainly through interviews and authors' on-site observations. Interviews were semi-structured and conducted at the respective companies. We had a questionnaire with two parts. Part A consisted of questions related to the influence of five categories of remanufacturing framework, and regarding the company's intention to outsource or not, and whether they would remanufacture in-house immediately or later. The remanufacturing issues on the questionnaire, which were developed based on a thorough review of the literature, were first tested with the Head of Production of one of the companies 
who has over four (4) years at top management level. This helped the research team to evaluate the effectiveness and comprehensiveness of the survey instrument and to refine it based on the feedback received (A summary of survey instrument is given in Appendix). The final survey instrument requested respondents to make paired comparisons of the remanufacturing strategic issues and to state the importance of factors for a pairwise comparison using Saaty's 9 point scale (Saaty, 1980; Saaty, 2008). Part B had questions related to the profile of respondents and the organizations. Additional questions were asked through telephone, email and follow-up interviews with the respondents. In addition to the above, to ensure the external validity and to buffer against further criticism relating to issues of rigor this study used two cases with multiple respondents (Seuring, 2008; Stuart et al., 2002).

\subsection{Analytic hierarchy process}

Following data collection, the Analytic Hierarchy Process (AHP) - a multi-criteria decisionmaking (MCDM) technique suitable for both qualitative and quantitative analysis was applied (Saaty, 2008). Among the various MCDM techniques proposed, the AHP proposed by Saaty (1980) is very popular and has been applied in a wide variety of areas including planning, selecting a best alternative, resource allocation and resolving conflicts. AHP is mostly used for its effective and adequate means of capturing the independent effects of the different factors in a multi-criteria decision-making process. Review articles illustrated the applicability of AHP to a wide variety of real problems with cases in different sectors beyond simple choice problems. Pohekar and Ramachandran, (2004) analysed the applicability of multi criteria decision making methods in 90 published articles related to sustainable energy planning and found that AHP is the most popular method compared with PROMETHEE and ELECTRE (Subramanian and Ramanathan, 2012). 
We aim to capture the independent effect of the factors in the decision making process. AHP was therefore used in our study. Another interesting aspect in the factors considered is overlapping. We recognised that, for instance, tax and subsidy can be both regulatory issues and financial issues. Also, the availability of a skilled workforce may also influence the technical issues. An Analytic network process (ANP) rather than an AHP can deal with such interdependency. However, the use of an ANP may make it too complex and possibly incomprehensible to managers/policy makers. For example, the questionnaire for an ANP for the 5 criteria with 16 sub-criteria identified in this study will be far more complex than that for an AHP since an ANP needs to compare the relative importance of each alternative both within and between clusters. Besides the above, the adequacy of an AHP in satisfying the objective of this study i.e. figure out the relative importance of various remanufacturing factors and to cover as many factors as possible to give a complete overview of remanufacturing issues made us to choose an AHP instead of an ANP.

We recognize that the factors identified may interact / influence each other and the interactions will be interesting to know, as stated in the limitations of this study. These limitations, we believe, do not negate the findings, insights and usefulness of this present study. Recently Charan et al., (2012) used the AHP model for the "Selection of service supply chain value creating perspective" while Bruno et al., (2012) used the AHP model for supplier evaluation.

The application of the AHP to a decision making problem involves four steps (Zahedi, 1986; Ramanathan, 2006). 


\section{STEP 1: Structuring of the decision problem}

The problem structure is divided into goals, criteria and alternatives. Our AHP model (Figure 1) has three levels: goals, factors and alternatives. While each sub-factor (see Table 2) was explained and exhaustively discussed, they are not included in the hierarchical model to avoid complexity of too many pair-wise comparison matrices and to avoid suppressing the original objective of the study.

STEP 2: Making pair-wise comparisons and obtaining the judgmental matrix In this step a pairwise comparison was made to determine the priority weight of each individual factor. Each respondent was asked to first rate the relative importance of factors with respect to the goal and later on the relative importance of alternatives with respect to the factors. We involved three respondents in each company (see Table 3). The final priorities of factors and alternatives are an average of the three respondents from the company. As the primary concern for case studies are the construct validity, all survey variables used in this study were adopted from literature, and the majority of them based on Subramoniam, et al. (2013), with suitable contextual modifications (see appendix).

STEP 3: Computing local weights and consistency of comparisons

Expert Choice software was used to perform an individual pairwise comparison matrix for ranking the factors with respect to the goal, and alternatives with respect to the factors. We also performed sensitivity analysis (a consistency index $(\mathrm{CI})$ ) to measure the inconsistency of each pairwise comparison (Saaty, 1980; Saaty, 2008, Subramoniam et al., 2013). The consistency index $(\mathrm{CI})$ and consistency ratio $(\mathrm{CR})$ of respondent's pairwise comparison satisfies the recommended value of less than 0.1 (Saaty, 1980). This shows the establishment 
of required consistency in respondents' judgment and does not necessitate further engagement with the survey participants to redo their initial priorities.

STEP 4: Aggregation of local weights

Final weights are an aggregation of local weights of the criteria and its importance. By definition, the weights of alternatives and importance of criteria are normalized so that they sum to unity. The final weights of the three alternatives are shown in figure 2 .

------INSERT FIGURE 1 ABOUT HERE -----

\section{RESULTS}

First, overall findings in each company investigated are highlighted, followed by a comprehensive comparative outcomes with respect to the factors investigated in both companies.

\subsection{Automotive Company A}

The result shows that Company A's overall decision is in favor of in-house remanufacturing, with a significant comparative decision outcome of 0.614 as opposed to outsourcing remanufacturing (0.245) and/or postponing remanufacturing (0.141) (see Fig. 2). Company A sees clear benefits in remanufacturing, especially with respect to better control of its products and its planned objective of moving up the value chain from OEM to ODM. The company finds technical issue of reverse logistics (RL) (take-back of cores and components), management issue of organizational integration, financial issue of low profitability of remanufactured products and regulatory issues of lack of enforceable take-back laws as the predominant factors in its remanufacturing implementation decisions. 


\subsection{Automotive Company B}

The result shows that Company B's overall decision is in favor of in-house remanufacturing, albeit with a low comparative decision outcome of 0.470 as opposed to outsourcing remanufacturing (0.346) and/or postponing remanufacturing (0.184) (see Fig. 2). Company B sees technical issue of recoverability of cores and material matching, management issue of skilled workforce, financial issues of low profitability of remanufactured products and tax and subsidy support, market issues of customer demand and products proliferation and regulatory issues of environmental protection as the predominant factors in remanufacturing decisions in the company.

\subsection{Comparative outcome with respect to factors}

The overall comparative decision outcome on whether to remanufacture in-house, outsource or postpone remanufacturing by the investigated companies is shown in Figure 2.

\section{------INSERT FIGURES 2 \& 3 ABOUT HERE -----}

\subsubsection{Technical issues}

The relative importance of the main factors governing remanufacturing is presented in Figure

3. The results show that technical concerns are the predominant factor for both companies investigated, with more than a 50\% weighting in each case.

Company A highly values reverse logistics (RL) operations whereas Company B seems to be optimistic about RL operations. To a certain extent both companies are involved in RL. Company B, for example, outsourced its failed parts recycling job to a third party both 
domestically and abroad and sees no big issues with that. Company A however was 'forced to' establish a new subsidiary to take care of its scrap after its collaboration with a third party failed because of the collaborator's inability to sort and manage resources properly. The two companies diverge greatly on whether the recoverability and the remanufacturability of the core is the major concern (see Figure 4). This difference is probably a reflection of their perception towards the competence of Chinese third party reverse logistics service providers.

Company B regards remanufacturing issues as a bigger challenge for the company, especially the core recoverability and material matching. Company A on the other hand finds these issues important, but inferior to RL. This may relate to the knowledge of the interviewees towards remanufacturing. The shop-floor manager from Company B used to work in the household appliance division of the same group and is a member of the China Household Electronics Appliance Association. Therefore, he would be more aware of the technical difficulties in the process as remanufacturing which has been widely used in the appliances industry in China. Recoverability of used material and the match of the parts to the core were mentioned in particular during the interview. However, it is worth noting that what the manager meant by recoverability and material match are quite different from what is commonly addressed in the literature with regards to proliferation and the increasing diversity of parts (Guide et al., 1999; Hammond et al., 1998). Managers were concerned with the high rate of obsolescence of the technologies in the automobile industry due to frequent and fast upgrades. They see this as major impediment to having an industry standard. For example, the proportion of plastic material compared with metal has recently increased significantly, making old parts, though reusable, functionally useless. The premise here seems to be that managers assume the major source of vehicle take-back for recycling or remanufacturing are from those that have reached their end-of-life. Other sources from which products to be 
remanufactured can originate from (such as, customer returns and/or cancelled orders, warranty related returns, demonstration/trial vehicle that can no longer pass as new) are not taken into consideration. In addition, it can also be a reflection of the defective Chinese secondary vehicle market. We believe that managers are rather oversimplifying the complexity of the technical issues involved. Overall, the above findings on technical difficulties are in line with the interview results as both managers recognized the large technological gap between the Chinese domestic and foreign auto-parts manufacturers. The finding is also in line with a previous study which suggests a common technological gap between developed and less developed nations (Mukherjee and Mondal, 2009).

\section{------INSERT FIGURE 4 ABOUT HERE -----}

\subsubsection{Management Issues}

Regarding managerial issues, both companies see no barriers with respect to top management support for remanufacturing despite a slight difference in weights (Figure 3). Company B attaches more importance to top management support for remanufacturing compared with Company A, which sees this factor as of little significance. Company A regards organizational integration as the predominant factor while Company B gives similar importance to a skilled workforce. Regarding the differences of attitude towards the importance of a skilled workforce, Company A has a better pool of human resources because it invests heavily in campus recruitment activities among top universities in China and hiring experienced engineers from around the world. According to Company A's Head of Production, it has a talent base of 600 specialists and several engineers that have worked in the United States for many years before joining the company whereas Company B's workforce are mostly locally trained with no international working experience. 
Though both companies reached some consensus on the relative importance of overall managerial issues towards remanufacturing decisions, great disparities exist with respect to each sub-criterion (Figure 5). These disparities can be justified from several aspects. A key aspect of the differences stems from their different organizational structures. Although both companies started from a small factory in the 1990s, the two companies developed along different paths. While auto-parts remains the core business for Company A, Company B has developed into a larger group with 7 core businesses, including appliances and a hot spring business. Also, while Company B remains a family business, Company A has involved more professional managers with various backgrounds in the management team. For instance, one of the $\mathrm{R} \& \mathrm{D}$ managers interviewed is from Taiwan. This more diversified management team in Company A has makes it more able to respond more positively to innovation compared with Company B that has a hierarchical organizational structure and is family run. The Company B method may operate well under the current manufacturing process, but remanufacturing includes more complexity and uncertainty in nature, therefore the existing methods of focusing locally may not be sufficient to support the establishment of remanufacturing.

The organizational integration concern for Company A comes mainly from two directions. Firstly, the organization is preparing a big, new project to develop electric vehicles in a new manufacturing center. The management team is experiencing great difficulty in integrating the new division with the existing business. Also, a just-in-time (JIT) service has recently been introduced to improve response to customers' demands, meaning a tighter connection with consumers is required. Company $\mathrm{B}$, on the contrary, has a relatively stable organizational structure. 


\section{------INSERT FIGURE 5 ABOUT HERE -----}

\subsubsection{Financial issues}

The financial issues reflect the expectation of the remanufactured products' profitability level and investment strategy of a company (see Figure 6). Both companies investigated attached low expectation on the overall profitability of remanufactured products. We believe that this is because of the possibility of new product market cannibalization by remanufactured product, as explained by the companies. Surprisingly 'financial issue' is of little concern to both firms, accounting for 0.13 and 0.059 respectively (Figure 3 ). Both companies recognized remanufacturing may require a large initial investment, but the perception towards this again differs greatly (Figure 5). While financing is not regarded by both companies as a major barrier, both have different investment priorities. For example, Company A, is already involved in a large project which has led to a tightening of its cash flow and the company is therefore reluctant to commit to other big investments. Company A can only focus on shortterm profitability to maintain good stock performance, despite the fact that it is three times more profitable than Company B. Company B, however, greatly values profitability and tax incentives, but pays little attention to upfront investment. The issue of finance as not being an impediment to implementing remanufacturing is contrary to many past studies in which financial issues have been rated as the most important factor and the bottom line for improvement (Sandvall and Stelin, 2006; Subramoniam et al., 2013). This finding might be a reflection of the great reserves of capital now available to both firms after their recent public listings. 


\subsubsection{Regulatory issues}

With regard to regulatory issues, there was consensus by both firms with respect to regulatory and social issues with almost negligible importance. Interestingly, both companies seem more familiar with foreign rather than domestic legislation. This is probably due to the lack of strict enforcement of domestic regulations. Take-back and recovery regulations like the Block Exemption Regulation 1400/2002 (BER), WEEE are already affecting both companies' business. Company A, for example, is required by its BMW's factory in South Africa to takeback and recycle all packages. It also shoulders the cost of sorting foam filling from paper packaging in line with the EU recovery laws. Nevertheless, both companies admitted having little knowledge of the latest Chinese regulations towards the pioneering program and advocacy for remanufacturing.

\section{------INSERT FIGURE 7 ABOUT HERE -----}

\subsubsection{Market issues}

On market issues, Company A gives almost no importance to market issues but Company B sees it as the second most important issue (with the same importance as management issues). Both companies are concerned that the introduction of remanufactured products may influence their existing product lines. This is in line with Guide and Li (2010) finding that commercial products face a higher risk of market cannibalization from a remanufactured one. With regards to customer demand for green products, Company B presumes that Chinese customers find remanufactured products inferior which may affect the image and reputation of the firm, and negatively influence the sales of remanufactured products. Company A, however, values a green image as a positive predominant factor with regard to market issues. Company A recognizes that remanufacturing is not only a sustainable and effective cost- 
saving business practice with additional environmental benefits, but it could also help the company overcome the increasing green trade barrier (GTB) from its overseas' customers.

As can be seen from our results, the perceptions of both companies towards market issues reached little consensus except for product proliferation (see Figure 8). We believe that the different views on green products are not unconnected with the different business models pursued by these two companies. For example, Company B is a typical OEM that manufacture-to-print in accordance with its existing customers' orders. It therefore does not have any incentive to change without serious customers' demand for the change. Company A, however, is more forward-looking - progressing towards Original Design Manufacturer (ODM) level, upgrading facilities and hiring highly rated professional managers with varied backgrounds. It also recently established design centers in Munich and Tokyo. These moves have seen Company A witnessing both tighter connectivity and relatively better bargaining power on its products over its customers. In addition to its gradual upward move in the industry, the value chain from OEM to ODM, Company A is listed on the Hong Kong Stock Exchange where sustainability issues are being taken more seriously than when compared with the Shenzhen Stock Exchange on mainland China where Company B is listed. Company A therefore has greater international exposure, better awareness and capabilities to implement remanufacturing when compared with Company B. This may explain why Company A has positive views on green products compared with Company B with its less internalization and capabilities. In general, both companies are clearly concerned about possible cannibalization and customers' perception of their image and reputation with respect to remanufactured products. 


\section{DISCUSSIONS}

Overall, our findings indicate the final rankings of the three alternatives from the aggregated weights on the five criteria: technical issues, management issues, financial issues, regulatory issues as well as market issues, provided for Company A and Company B respectively. Both companies acknowledged that remanufacturing is a fruitful option and in-house remanufacturing is a better solution when compared with outsourcing. However, neither company is planning to conduct in-house remanufacturing in the next three years due to a lack of capability from the identified technical issues perspective.

To avoid large upfront investment and solve short-term cash flow problems, few companies in China consider outsourcing remanufacturing activities to be a great short-term alternative method. The capability of third-parties is a major hindrance in China and companies believe that establishing and maintaining their own logistic function would be more desirable. Additionally, possible organizational disorder is foreseen by the managers, especially with respect to outsourcing. It is more appealing to managers that $\mathrm{RL}$, rather than the remanufacturing operation, should be outsourced. Companies are clearly concerned about possible new product market cannibalization by similar remanufactured products and customers' negative perception of their image and reputation with respect to remanufactured products.

Despite these identified issues, however, managers are in agreement that remanufacturing is a sound choice to gain a green image for their company and to also enjoy more government benefits, in addition to possible technological improvement brought by remanufacturing activities. Though managers expressed concerns for intellectual property, the influence is 
trivial given the weighting it receives (see Figure 7). Detailed insights based on our study and brief comparisons with western perspectives are given below.

\subsection{Technical issues}

Of the major characteristics of remanufacturing that seriously complicate its implementation in China, a lack of RL that enable the recoverability/availability of cores, the remanufacturability of the cores due to its design, part matching and recoverability are the key factors affecting decisions to engage in remanufacturing operations. Attention needs to be focused on these aspects if any meaningful remanufacturing is to occur in China going forward. Unlike in the west where RL is relatively well-practiced and has enabled companies to witness enhanced competitive gains through remanufacturing (Chapman, et al., 2010; Kapetanopoulou and Tagaras, 2011), RL is still a major obstacle in the companies investigated. The capability of third-parties is a major hindrance to RL outsourcing in China and companies believe that establishing and maintaining their own logistic function would be more desirable. Additionally, possible organizational disorder is foreseen by the managers, especially with outsourcing. It is more appealing to managers that RL, rather than the remanufacturing operation, should be outsourced. RL obstacles are in addition to the design, material matching and recoverability issues that are all unaligned with remanufacturing requirement (Hammond et al., 1998; Flapper et al., 2002; Rahman, Subramanian, 2011).

\subsection{Management issues}

In both companies investigated, top management support was not an obstacle to remanufacturing decision making. Management at both companies are fully aware of this global trend of take-back and remanufacturing cores and components in automotive industry. 
The finding that both companies see no barriers with respect to top management support for remanufacturing, can be attributed to the fact that our respondents themselves are the key members of the decision-making body in their respective companies. The twin management issues of the lack of skilled workforce and organizational integration are similarly reported as predominant barriers to a firm's decision to implement remanufacturing in the west (Mukherjee and Mondal, 2009; Kapetanopoulou and Tagaras, 2011). However, with both companies determined to only remanufacture in-house to safeguard quality and IP protection, significant investment in remanufacturing related $R \& D, R L$ and workforce training will be required.

\subsection{Financial Issues}

Our study reveals that finance is of relatively less significance when compared with technical capability. The key financial issue with respect to the decision on whether to embark on any of the three decision alternatives does not appear to center on the significant upfront investment decision. Rather, it is centered on the perceived relatively low profitability of remanufactured products and possible new product market cannibalization by similar remanufactured products. This finding suggests that tax incentives and subsidies might become a more important driver for remanufacturing since companies can expect government subsidies and other favorable policies as a way to offset their investments and generate profit from their remanufacturing operation. In contrast to the above finding, past western studies have ranked financial issues of upfront investment as the most important strategic factor in implementing remanufacturing (Subramoniam et al., 2013; Hauser and Lund, 2008; Sandvall and Stelin, 2006). It therefore appears that for remanufacturing in China to fully take off, support and encouragement in terms of subsidies and VAT reduction as practiced in the west needs to be established and made available to all firms undertaking remanufacturing (Willis, 
2010). China currently offers subsidies on a limited range of vehicles such as small- and medium-sized old cars, yellow-sticker vehicles and the rural bus subsidy in its 'automotive replacement' policy, to encourage vehicle owners to submit vehicles to officially recognized end-of-life vehicle (ELV) dismantlers (Wang and Chen, 2013). While these subsidies are encouraging signs, they are relatively very low, time dependent, not comprehensive and/or effective. The policy is not effective because ELV owners still sell their old vehicles to the grey market that offers them a better price (Wang and Chen, 2013). The subsidy system is also not comprehensive as it excludes other categories of vehicles and the majority of components/parts manufacturers. For example, an unofficial estimate puts the number of car manufacturers in China to be around 120, in addition to thousands of parts manufacturers (Schmitt, 2011). However, only 14 automotive manufacturers were officially selected for the remanufacturing pilot project; The "Regulations of Remanufacturing Pilot of Automotive Parts"” of March 2008 (Xiang and Ming, 2011). We recommend the widening of the subsidy and the introduction of other forms of support and recognition to all companies with significant remanufacturing activities.

\subsection{Regulatory Issues}

A key factor that is likely to determine the future remanufacturing activities in China is essentially the enforcement of government regulatory laws such as the End-of-Life vehicles (ELVs) take-back and Extended Producer Responsibility (EPR) laws (Xiang, 2011). Strong IP protection in China is also identified as a concern by companies as a barrier to outsourcing their remanufacturing operation. This study reveals that most of China's automotive companies are more familiar with foreign rather than domestic legislations. The lack of familiarity with national legislation can be understood considering that most of the companies 
are not officially identified as part of the big polluters by the National Development and Reform Commission (NDRC) (Xiang and Ming, 2011).

However, the two major factors that have encouraged remanufacturing practices in the west and other developed economies are the strict enforcement of environmental legislations and/or the take-back / recovery of ELVs regulations and the protection of IP (Lai and Wong, 2012; Peng and Su, 2011; Pagell, 2007). China's policy makers need to align their regulatory and business practices to these western standards to boost remanufacturing and possible outsourcing of remanufacturing activities in China.

\subsection{Market issues}

The general perception that remanufacturing is driven by customers' demand for green products and promoted by a green image conferred by producers was not viewed positively by the investigated companies. According to these companies, most Chinese consumers consider remanufactured products as essentially inferior products that can only be purchased at a giveaway price compared with similar new products. This negative perception of remanufactured products by the Chinese consumers is a major concern to Chinese managers who worry about the possible brand damage they may face if they are seen to engage in remanufacturing. This leads to a severe disincentive for remanufacturing. Possible cannibalization of a new product market by remanufactured products following low prices is another major barrier to engaging in remanufacturing in China. These findings are essentially similar to those reported in the West and/or other developed economies. For example, despite greater transparency and relatively more enlightened consumers in the West, remanufactured products still suffer a negative outlook from consumers who are only prepared to pay less for such products (Kapetanopoulou and Tagaras, 2011). Similarly, the potential for possible cannibalization of new product sales by a remanufactured one from the 
same company is similarly reported in the West as a major impediment to remanufacturing (Guide and Li, 2010). Specially designed, transparent consumer awareness programs and marketing strategies for remanufactured products should alleviate some of these issues and boost remanufacturing.

\section{CONCLUDING REMARKS}

The study addresses relevant practical problems of sustainability in terms of remanufacturing in one of the world's most important industrial sectors, the automotive industry sector. The objective of this study was to develop a strategic decision-making framework for remanufacturing through a comprehensive review of the key issues governing remanufacturing practices, and to use the framework to examine and compare the status of remanufacturing in Chinese auto-parts companies with those from Western perspectives. This is important because the implementation of remanufacturing practices may be a risky endeavor for top management without a comprehensive understanding of those factors governing this complex set of activities called remanufacturing. The study identified key strategic factors that impact on the implementation of remanufacturing with respect to five factors: technical, management, financial, regulatory as well as market. It revealed that when compared with their western counterparts, technical concerns are predominant when deciding whether to implement remanufacturing in China's auto parts industry (more than $50 \%$ ) based on the investigated companies. Managers recognize that there is a large technological gap between the domestic and foreign auto-parts manufacturers and that this is a major factor inhibiting remanufacturing in their firms. Surprisingly, and contrary to the literature, Chinese managers do not consider regulatory and social issues as an important factor, as generally found in western and/or in other developed societies. We have attributed this finding to the overwhelming technical incapacity being experienced by the firms which 
has meant that government regulations have a lesser role in their decision making process. Overall, market factors play a less critical role, with one firm thinking it is not important, while the other considers it of secondary importance. Again, in contrast to many past western studies, in which financial issues have been rated the most important factor impacting on remanufacturing decisions and implementation, this was not the case in both firms investigated. Our inference is that the firms investigated have great reserves of capital from their going public at the time of this study. Furthermore, because both firms have no immediate plan for implementing remanufacturing, the managers are likely to be oblivious of the magnitude of the financial impact of its implementation to their respective firms. Management factors considered as major impediments to remanufacture in the two companies investigated are the lack of a skilled workforce and organizational integration. This is in line with literature that reports the same as predominant barriers to firms' decision to implement remanufacturing in the west.

As a contribution, this study addresses practical sustainability issues in terms of remanufacturing in China's key and fast growing industry: the automotive industry. The study can help managers and policy makers in the development of remanufacturing in China and other nations with less developed remanufacturing practices similar to China.

Despite the in-depth nature of this study due to using a case study and face-to-face interviews, and despite the useful insights gained into the issues affecting Chinese remanufacturing practices, valuable insights could be gained through future large-scale empirical surveys across different Chinese cities that take into consideration the moderating effects of company size, efficiency and performance of the investigated companies. The use of other methodologies such as an ANP to understand the interdependency of the factors and subcriteria considered in this study and the relative importance of each alternative both within 
and between clusters appears warranted. Future studies using other methodologies as suggested above are needed to confirm (or refute) our findings while future large-scale empirical studies will enable greater generalization of the findings across China.

\section{Acknowledgments}

The authors would like to thank the Ningbo Science and Technology Bureau, under the Innovation Team Project (Grant No. 2011B1006) for sponsoring this research. Also the authors are grateful to the subject editor and the anonymous reviewers for their critical and very insightful comments that have helped in improving the quality of this paper.

\section{Appendix: Questionnaire used for the survey (AHP section)}

Please use the scale of 1 to 9, with 1 being of 'Equal importance', and with 9 being of 'Extreme importance', in answering all of the questions below (please note that in the tables, the value of 1 has been assigned where each element diagonally corresponds to itself, implying the element is of equal importance to itself):

Please rate the relative importance of each of the following factors: 'Technical issues', 'Management issues', 'Financial issues', 'Regulatory issues', and 'Market issues' towards strategic decision to implement remanufacturing in your company

\section{Strategic decision making to implement remanufacturing}

Please rate the relative importance of 'Technical issues' on (Management, Financial, Regulatory and environmental, Market) issues towards strategic decision to implement remanufacturing in your company.

Please rate the relative importance of 'Management issues' on (Technical, Financial, Regulatory and environmental, Market) issues towards strategic decision to implement remanufacturing in your company.

Please rate the relative importance of 'Financial issues' on (Technical, Management, Regulatory and environmental, Market) issues towards strategic decision to implement remanufacturing in your company.

Please rate the relative importance of 'Regulatory issues' on (Technical, Management, Financial, Market) issues towards strategic decision to implement remanufacturing in your company.

Please rate the relative importance of 'Market issues' on (Technical, Management, Financial, Regulatory issues) issues towards strategic decision to implement remanufacturing in your company.

Alternative remanufacturing implementation decision

Please rate the relative importance of engaging in 'In-house remanufacturing' on (Technical issues, Management issues, Financial issues, Regulatory issues, and Market issues) in strategic decision to implement remanufacturing in your company.

Please rate the relative importance of 'Outsourcing remanufacturing' on (Technical issues, Management issues, Financial issues, Regulatory issues, and Market issues) in strategic decision to implement remanufacturing in your company. 
Please rate the relative importance of 'Postponing remanufacturing' on (Technical issues, Management issues, Financial issues, Regulatory issues, and Market issues) in strategic decision to implement remanufacturing in your company.

\section{Technical issues}

Please rate the relative importance of 'Reverse logistics' on (Design issue, Material matching, and Recoverability of cores) towards strategic decision to implement remanufacturing in your company.

Please rate the relative importance of 'Design issue' on (Reverse logistics, Material matching, and Recoverability of cores) towards strategic decision to implement remanufacturing in your company.

Please rate the relative importance of 'Material matching' on (Reverse logistics, Design issue, and Recoverability of cores) towards strategic decision to implement remanufacturing in your company (Please use scale between $1 . . . .9$ as explained).

Please rate the relative importance of 'Recoverability of cores' on (Reverse logistics, Design issue, and Material matching) towards strategic decision to implement remanufacturing in your company.

\section{Management issues}

Please rate the relative importance of 'Top management support' on (Availability of skilled workforce, and Organisational integration) towards strategic decision to implement remanufacturing in your company.

Please rate the relative importance of 'Availability of skilled workforce' on (Top management support, Organisational integration) towards strategic decision to implement remanufacturing in your company.

Please rate the relative importance of 'Organisational integration' on (Top management support, and Availability of skilled workforce) towards strategic decision to implement remanufacturing in your company.

\section{Financial issues}

Please rate the relative importance of 'Need for upfront financial investment' on (Profitability of remanufactured products, Tax /subsidy support) towards strategic decision to implement remanufacturing in your company.

Please rate the relative importance of 'Profitability of remanufactured products' on (Need for upfront financial investment, Tax / subsidy) towards strategic decision to implement remanufacturing in your company.

Please rate the relative importance of 'Tax/subsidy' on (Need for upfront financial investment, and Profitability of remanufactured product) towards strategic decision to implement remanufacturing in your company.

\section{Regulatory and environmental issues}

Please rate the relative importance of 'Product take-back / recovery' on (Environmental legislations, and Intellectual property protection) towards strategic decision to implement remanufacturing in your company.

Please rate the relative importance of 'Environmental legislations' on (Product take-back / recovery, and Intellectual property protection) towards strategic decision to implement remanufacturing in your company.

Please rate the relative importance of 'Intellectual property protection' on (Product take-back / recovery, and Environmental legislations) towards strategic decision to implement remanufacturing in your company. 
Please rate the relative importance of 'Customer demand' of remanufactured product on (Green image of remanufactured products, and New product market cannibalisation by remanufactured product) towards strategic decision to implement remanufacturing in your company.

Please rate the relative importance of 'Green image of remanufactured products' on (Customer demand of remanufactured products, and New product market cannibalisation by remanufactured product) towards strategic decision to implement remanufacturing in your company.

Please rate the relative importance of 'New product market cannibalisation by remanufactured product' on (Green image of remanufactured products, and Customer demand of remanufactured products) towards strategic decision to implement remanufacturing in your company. 


\section{REFERENCES}

Atasu, A., et al., 2010. So what if remanufacturing cannibalizes my new product sales? California Management Review, 52.

Atasu, A., Sarvary, M. and Wassenhove, LNV., 2005. Remanufacturing as a Marketing Strategy. Management Science, 54, 1731-1746.

Amighini, A. A., 2012. China and India in the international fragmentation of automobile production. China Economic Review, 23, 325-341

Barker, T.J. and Zabinsky, B.Z. A., 2011. Multicriteria decision making model for reverse logistics using analytical hierarchy process. Omega, 39, 558-573

Bellman, K. and Khare, A., 2000. Economic issues in recycling end-of-life vehicles. Technovation, 20, 677-690

Bras. B. and Mcintosh, M.W., 1999. Product, process, and organizational design for remanufacture: an overview of research. Robotics and Computer Integrated Manufacturing, 15.

Bruno, G., et al., 2012. AHP- based approaches for supplier evaluation: Problems and perspectives. Journal of Purchasing \& Supply Management, http://dx.doi.org/10.1016/j.pursup.2012.05.001

Carpenter, M.A., 2002. The implications of strategy and social context for the relationship between top management team heterogeneity and firm performance. Strategic Management Journal, 23, 275-284.

Chapman, A., et al., 2010. Remanufacturing in the UK: A snapshot of the UK remanufacturing industry. Lancaster: Center for Remanufacturing and Reuse.

Charan, P., Madaan, J. and Khare, A., 2012. Selection of service supply chain value creating perspective using AHP approach. Proceedings of POMS 23rd Annual Conference, Chicago, Illinois, U.S.A. April 20 to April 23, 2012

Chen, M. and Zhang, F., 2009. End-of-Life Vehicle Recycling in China: Consideration and Innovation following the EU ELV Directive. Journal of the Minerals, Metals and Materials Society; 61 (3), 45-52.

Chen, J.M. and Chang, C.I., 2012. The co-operative strategy of a closed-loop supply chain with remanufacturing. Transportation Research Part E, 48, 387-400

Chung, C.J. and Wee, H.M., 2010. Green-product-design value and information-technology investment on replenishment model with remanufacturing. International Journal of Computer Integrated Manufacturing, 23, 466-485.

Copenhageneconomics., 2007. Study on reduced VAT applied to goods and services in the Member States of the European Union. Denmark 2007.

Curtis S., Gesler W., Smith G., Washburn S., 2000. Approaches to sampling and case selection in qualitative research: examples in the geography of health. Social Science \& Medicine, 50, 1001-1014.

Dowlatshahi, S., 2005. A strategic framework for the design and implementation of remanufacturing operations in reverse logistics. International Journal of Production Research, 43 (16), 3455-3480 
Dyer, W.G., and Wilkins, A.L., 1991. Better stories, not better constructs, to generate better theory: a rejoinder to Eisenhardt. Academy of Management Review, 16(3), 613-619.

Eisenhardt, K.M., 1989. Building theories from case study research. Academy of Management Review, 14 (4), 532-50.

Ferrer, G. and Whybark, D.C., 2001. Material Planning For A Remanufacturing Facility. Production and Operations Management, 10, 112-124.

Ferrer, G. and Swaminathan, J.M., 2006. Managing New and Remanufactured Products. Management Science, 52, 15-26.

Ferrer, G. and Swaminathan J.M., 2010. Managing new and differentiated remanufactured products. European Journal of Operational Research, 203, 370-379.

Flapper, SDP. and Fransoo, J.C., Broekmeulen RACM, Inderfurth K., 2002. Planning and control of rework in the process industries: A review. Production Planning \& Control, $13,26-34$.

Franke, C., Basdere, B., Ciupek, M. and Seliger, S., 2006. Remanufacturing of mobile phones-capacity, program and facility adaptation planning. Omega, 34(6), 562-570.

Geyer, R. and Jackson, T., 2004. Supply Loops and Their Constraints: The Industrial Ecology of Recycling and Reuse. California Management Review, 46.

Giannetti, B.F., Bonilla, S.H. and Almeida, CMVB., 2012. An emergy-based evaluation of a reverse logistics network for steel recycling, Journal of Cleaner Production, doi: 10.1016/j.jclepro.2012.05.024.

Guide, VDR. And Van Wassenhove, L.N., 2001. Managing Product Returns For Remanufacturing. Production and Operations Management, 10, 142-155.

Guide, VDR. and Li, J., 2010. The Potential for Cannibalization of New Products Sales by Remanufactured Products. Decision Sciences, 41, 547-572.

Guide, VDR., 2000. Production planning and control for remanufacturing: industry practice and research needs. Journal of Operations Management, 18, 467-483.

Guide, VDR, Jayaraman, V. and Srivastava, R., 1999. Production planning and control for remanufacturing: a state-of-the-art survey. Robotics and Computer-Integrated Manufacturing, 15, 221-230.

Hambrick, D.C., 2007. Upper Echelons Theory: An Update The Academy of Management Review, 32, 334-343.

Hammond, R., Amezquita, T. and Bras, B., 1998. Issues in the Automotive Parts Remanufacturing Industry -A Discussion of Results from Surveys Performed among Remanufacturers. International Journal of Engineering Design and Automation, 4(1), 27-46,

Hauser, W.M. and Lund, R.T., 2008. The remanufacturing industry: anatomy of a giant : a view of remanufacturing in America based on a comprehensive survey across the industry, Boston, Dept. of Manufacturing Engineering, Boston University. www.bu.edu/reman (accessed 10 July 2012)

Hazen, B.T., et al., 2012. The role of ambiguity tolerance in consumer perception of remanufactured products. International Journal of Production Economics, 135, 781790. 
Ijomah, W.L., 2009. Addressing decision making for remanufacturing operations and designfor-remanufacture. International Journal of Sustainable Engineering, 2, 91-102.

Jayaraman, V. and Luo, Y., 2007. Creating Competitive Advantages Through New Value Creation: A Reverse Logistics Perspective. Academy of Management Perspectives, 21(2), 56-73.

Junior M.L. and Filho M.G., 2011. Production planning and control for remanufacturing: literature review and analysis. Production Planning \& Control, 23(6), 419-435.

Kapetanopoulou, P. and Tagaras, G., 2011. Drivers and obstacles of product recovery activities in the Greek industry. International Journal of Operations \& Production Management, 31, 148-166.

Kleber, R., Zanoni, S. and Zavanella, L., 2011. On how buyback and remanufacturing strategies affect the profitability of spare parts supply chains. International Journal of Production Economics, 133, 135-142.

Kutta, R.M. and Lund, R.T., 1978. Remanufacturing: A Preliminary Assessment. Center for Policy Alternatives, Massachusetts Institute of Technology.

Lai, K-H. and Wong, CWY., 2012. Green logistics management and performance: Some empirical evidence from Chinese manufacturing exporters. Omega, 40, 267-282.

Martin, P., Guide, JVDR. and Craighead, C.W., 2010. Supply Chain Sourcing in Remanufacturing Operations: An Empirical Investigation of Remake Versus Buy. Decision Sciences, 41, 301-324.

Michaud, C. and Llerena, D., 2006. An economic perspective on remanufactured products: industrial and consumption challenges for life cycle engineering. 13th CIRP International Conference On Life Cycle Engineering, PROCEEDINGS OF LCE 2006. http://www.mech.kuleuven.be/lce2006/063.pdf (accessed 10 July 2012)

Miles, M. and Huberman, A., 1994. Qualitative Data Analysis. Sage, London, 34.

Mitra, S. and Webster, S., 2008. Competition in remanufacturing and the effects of government subsidies. International Journal of Production Economics, 111, 287-298.

Mukherjee, K. and Mondal, S., 2009. Analysis of issues relating to remanufacturing technology - a case of an Indian company. Technology Analysis \& Strategic Management, 21, 639-652.

Narasimhan, R., and Jayaram, J., 1998. Reengineering service operations: a longitudinal case study. Journal of Operations Management, 17 (1), 7-22.

Pagell, M., Wu, Z. and Murthy, N.N., 2007. The supply chain implications of recycling. Business Horizons, 50, 133-143.

Parlikad, A.K. and McFarlane, D., 2004. Recovering value from "End-of-Life" Equipment A Case Study on the Role of Product Information. Technical Report No. CUED/E$M A N U F / T R .29$, Centre for Distributed Automation and Control. University of Cambridge. $\quad$ http://www2.eng.cam.ac.uk/ aknp2/documents/Casestudyreport.pdf (accessed 02 January 2014)

Parlikad, A.K. and McFarlane, D., 2010. Quantifying the impact of AIDC technologies for vehicle component recovery. Computers \& Industrial Engineering, 59, 296-307. 
Parlikad, A.K. and McFarlane, D., 2007. RFID-based product information in end-of-life decision making. Control Engineering Practice, 15, 1348-1363.

Peng, Z.Q. and Su, P., 2011. On the licensing strategy of remanufacturing patented product under compulsory licensing E -Business and E -Government (ICEE) Shanghai.

Pohekar,S.D., Ramachandran, M., 2004. Application of multi-criteria decision making to sustainable energy planning - a review. Renewable and Sustainable Energy Reviews, $8,365-381$.

PwC, 2011. 15th Annual Global CEO Survey: Automotive industry insights. http://www.pwc.com/en_GX/gx/automotive/pdf/opportunities-to-improve-financialreporting-and-internal-controls-in-china-cas-and-c-sox.pdf (Assessed 13 December 2012).

Rahman, S. and Subramanian, N., 2011. Factors for implementing end-of-life computer recycling operations in reverse supply chains. International Journal of Production Economics, 140 (1), 239-248

Ramanathan, R., 2006. Data envelopment analysis for weight derivation and aggregation in the analytic hierarchy process. Computers \& Operations Research, 33, 1289-1307

Rogers, D. and Tibben-Lembke, R., 1999. Going Backwards: Reverse Logistics Trends and Practices. Reverse Logistics Executive Council, University of Nevada, Reno, NV.

Saaty, T.L., 1980. The Analytic Hierarchy Process: Planning, Priority Setting, Resource Allocation. McGraw-Hill, New York, NY, 437.

Saaty, T.L., 2008. Relative Measurement and Its Generalization in Decision Making Why Pairwise Comparisons are Central in Mathematics for the Measurement of Intangible Factors-The Analytic Hierarchy/Network Process. Review of the Royal spanish Academy of Sciences, Series A, Mathematics, 102, 251-318.

Sandvall, F. and Stelin, C., 2006. The Remanufacturing Offer A Case Study of Volvo Construction Equipment Implementing and Expanding Reman in Russia Author:. Bachelor Stockholm University.

Sarkis, J., Helms, M. and Hervani, A., 2010. Reverse logistics and social sustainability. Corporate Social Responsibility and Environmental Management, 17 (6), 337-354

Schmitt B., 2011. China Car Market 101: Who Makes All Those 18 Million Cars? http://www.thetruthaboutcars.com/2011/01/china-car-market-101-who-makes-allthose-18-million-cars/ (accessed 12 May 2013)

Seuring SA (2008) Assessing the rigor of case study research in supply chain management. Supply Chain Management: An International Journal, 13(2), 128-137.

Steinhilper, R., et al., 2011. New Technologies for Remanufacturing of Automotive Systems Communicating via CAN Bus Glocalized Solutions for Sustainability in Manufacturing. In: HESSELBACH, J. \& HERRMANN, C. (eds.). Springer Berlin Heidelberg.

Stock, J., Speh, T. and Shear, H., 2006. Managing product returns for competitive advantage. MIT Sloan Management Review, 48, 1. 
Stuart, I., McCutcheon,D., Handfield, R., McLachlin, R., Samson, D., (2002), Effective case research in operations management: a process perspective. Journal of Operations Management, 20, 419-433.

Srivastava, S.K. and Srivastava, R.K., 2006. Managing product returns for reverse logistics. International Journal of Physical Distribution \& Logistics Management, 36, 524-546.

Subramanian N \& Ramanathan R (2012) A review of applications of Analytic Hierarchy Process in operations management. International Journal of Production Economics, 138(2), 215-241.

Subramoniam, R., Huisingh, D. and Chinnam, R.B., 2009. Remanufacturing for the automotive aftermarket-strategic factors: literature review and future research needs. Journal of Cleaner Production, 17, 1163-1174.

Subramoniam, R., Huisingh, D. and Chinnam, R.B., 2010. Aftermarket remanufacturing strategic planning decision-making framework: theory \& practice. Journal of Cleaner Production, 18, 1575-1586.

Subramoniam, R., Huisingh, D., Chinnam, R.B., Subramoniam, S., 2013. Remanufacturing Decision-Making Framework (RDMF): research validation using the analytical hierarchical process. Journal of Cleaner Production, 40, 212-220.

Toffel, M.W., 2004. Strategic Management of Product Recovery. Strategic Management of Product Recovery, 46.

Um, J., Yoon, J.-S. and Suh, S.-H., 2008. An architecture design with data model for product recovery management systems. Resources, Conservation and Recycling, 52(10), $1175-1184$.

USITC, 2012. Remanufactured Goods: An Overview of the U.S. and Global Industries, Markets, and Trade. http://www.usitc.gov/publications/332/pub4356.pdf (Accessed 25 February 2014).

Voss, C.A., Tsikriktsis, N. and Frohlich, M., 2002. Case research in operations management. International Journal of Operations \& Production Management, 22 (2), 195-219.

Wacker, J.G. (1998), A definition of theory: research guidelines for different theory-building research methods in operations management. Journal of Operations Management, 16, $361-385$.

Wang, L., and Chen, M., 2013. Policies and perspective on end-of-life vehicles in China. Journal of cleaner production, 44, 168-176.

Webster, S., and Mitra, S., 2007. Competitive strategy in remanufacturing and the impact of take-back laws. Journal of Operations Management, 25, 1123-1140.

Willis, P., 2010. Market Failures in Remanufacturing: An examination against major categories by Aylesbury: Centre for Remanufacturing \& Reuse. www.remanufacturing.org.uk (accessed 23 July 2012 )

$\mathrm{Wu}, \mathrm{C}-\mathrm{H} ., 2012$. Price and service competition between new and remanufactured products in a two-echelon supply chain. International Journal of Production Economics, 140 (1), 496-507.

$\mathrm{Wu}, \mathrm{C}-\mathrm{H} ., 2$ 2013. OEM product design in a price competition with remanufactured product. Omega, 41, 287-298. 
Xiang, W., and Ming, C., 2011. Implementing extended producer responsibility: vehicle remanufacturing in China. Journal of cleaner production, 19, (6-7), 680-686.

Zahedi, F., 1986. The analytic hierarchy process - A survey of the method and its applications. Interfaces, 16, 96-108.

Zhang, T., Chu, J., Wang, X., Liu, X., and Cui, P., (2011), Development pattern and enhancing system of automotive components remanufacturing industry in China. Resources, Conservation and Recycling, 55 (6), 613-622. 


\section{TABLES}

Table 1 Comparison between various product recovery alternatives

\begin{tabular}{llll}
\hline $\begin{array}{l}\text { Recovery } \\
\text { alternatives }\end{array}$ & $\begin{array}{l}\text { Functional } \\
\text { status }\end{array}$ & $\begin{array}{l}\text { Type of } \\
\text { supply chain }\end{array}$ & $\begin{array}{l}\text { Value } \\
\text { reclaim }\end{array}$ \\
\hline Reuse & Original & Close-loop & Deteriorating \\
Repair & Original & Close-loop & Partial recovery \\
Recycle & New & Open-loop & Back to unit level \\
Remanufacture & Original & Close-loop & Value-added \\
\hline
\end{tabular}

Table 2 Summary of strategic remanufacturing factors

\begin{tabular}{|c|c|c|}
\hline Factors & Sub-factors & Source \\
\hline \multirow[t]{4}{*}{ Technical issues } & Reverse logistics & $\begin{array}{l}\text { Guide, 2000; Rahman and Subramanian, 2011; } \\
\text { Fleischmann et al., 1997; Rogers and Tibben- } \\
\text { Lembke, 1999; Parlikad and McFarlane, 2004; } \\
\text { Dowlatshahi, 2005; Subramanian et al., 2009 }\end{array}$ \\
\hline & Design issues & \multirow{3}{*}{$\begin{array}{l}\text { Dowlatshahi, 2005; Franke et al., 2006; Um et } \\
\text { al., 2008; Chung and Wee, 2010; Parlikad and } \\
\text { McFarlane, 2010; Guide et al., } 1999\end{array}$} \\
\hline & Material matching & \\
\hline & Recoverability & \\
\hline \multirow[t]{3}{*}{$\begin{array}{l}\text { Management } \\
\text { issues }\end{array}$} & $\begin{array}{l}\text { Top management } \\
\text { team support }\end{array}$ & Carpenter, 2002; Hambrick, 2007 \\
\hline & $\begin{array}{l}\text { Availability of } \\
\text { skilled workforce }\end{array}$ & $\begin{array}{l}\text { Kapetanopoulou and Tagaras, 2011; Subramanian } \\
\text { et al., } 2009\end{array}$ \\
\hline & $\begin{array}{l}\text { Need for } \\
\text { organizational } \\
\text { integration }\end{array}$ & Michaud and Llerena, 2006 \\
\hline \multirow[t]{3}{*}{ Financial issues } & $\begin{array}{l}\text { Need for upfront } \\
\text { financial investment }\end{array}$ & $\begin{array}{l}\text { Subramoniam et al., 2010; Subramoniam et al., } \\
2013\end{array}$ \\
\hline & $\begin{array}{l}\text { Profitability of } \\
\text { remanufactured } \\
\text { products }\end{array}$ & Hauser and Lund, 2008 ; Kleber, 2011 \\
\hline & Tax \& subsidy & Willis, 2010 \\
\hline \multirow[t]{2}{*}{$\begin{array}{l}\text { Regulatory \& } \\
\text { environmental } \\
\text { issues }\end{array}$} & $\begin{array}{l}\text { Product take-back \& } \\
\text { recovery legislations } \\
\text { Environmental } \\
\text { regulation }\end{array}$ & $\begin{array}{l}\text { Webster and Mitra, 2007; Parlikad and } \\
\text { McFarlane, 2007; Subramanian et al., } 2009\end{array}$ \\
\hline & $\begin{array}{l}\text { Intellectual property } \\
\text { protection }\end{array}$ & Martin and Guide, 2010 \\
\hline \multirow[t]{2}{*}{ Market issues } & $\begin{array}{l}\text { Customer demand } \\
\text { Green image of } \\
\text { remanufactured } \\
\text { products }\end{array}$ & $\begin{array}{l}\text { Geyer and Jackson, 2004; Michaud and Llerena, } \\
\text { 2006; Parlikad and McFarlane, } 2007\end{array}$ \\
\hline & $\begin{array}{l}\text { Product } \\
\text { Cannibalization }\end{array}$ & $\begin{array}{l}\text { Atasu et al., 2010; Ferrer and Swaminathan, 2006; } \\
\text { Mitra and Webster, 2008; } \\
\text { Hazen et al., 2012; Michaud and Llerena, } 2006\end{array}$ \\
\hline
\end{tabular}


Table 3 Respondent profile

\begin{tabular}{|c|c|c|}
\hline Characteristics & Company A & Company B \\
\hline Ownership & $\begin{array}{l}\text { Foreign invested (listed in Hong } \\
\text { Kong stock Exchange) }\end{array}$ & $\begin{array}{l}\text { Private (listed in Shenzhen } \\
\text { Stock Exchange) }\end{array}$ \\
\hline Main product & $\begin{array}{l}\text { Starter motors, alternators, } \\
\text { brakes, water pumps, body } \\
\text { structural parts, trims and } \\
\text { decorative parts of passenger } \\
\text { vehicles }\end{array}$ & $\begin{array}{l}\text { Alternators, brakes, } \\
\text { clutches, air conditioners, } \\
\text { air-conditioning control } \\
\text { series, Door panel series, } \\
\text { Stamping parts and tube } \\
\text { auto-seating series }\end{array}$ \\
\hline Plant Location & $\begin{array}{l}14 \text { domestic subsidiaries } \\
\text { Sales and Design Centers in } \\
\text { Tokyo, Munich, and Detroit } \\
\text { Production Facilities in the US, } \\
\text { Thailand, and Mexico }\end{array}$ & $\begin{array}{l}16 \text { domestic subsidiaries } \\
2 \text { overseas representative } \\
\text { offices in North America } \\
\text { and Europe }\end{array}$ \\
\hline Type of organization & Joint venture & Private \\
\hline Year of establishment & 1992 & 1986 \\
\hline Annual turnover & $¥ 3878$ mil (US\$633 mil) & $¥ 1360 \mathrm{mil}$ (US\$222 mil) \\
\hline $\begin{array}{l}\text { Years of Experience in } \\
\text { Reverse logistics \& Return } \\
\text { management }\end{array}$ & $3-5$ & $4-7$ \\
\hline $\begin{array}{l}\text { No. of staff in logistics \& } \\
\text { SCM }\end{array}$ & 11 & 15 \\
\hline Main clients & $\begin{array}{l}\text { Renault Nissan Alliance } \\
\text { Volkswagen AG, GM, BMW }\end{array}$ & $\begin{array}{l}\text { GM, Ford, Toyota, DFAC, } \\
\text { Faurecia, Valeo, Bosch }\end{array}$ \\
\hline Position of respondent & $\begin{array}{l}\text { Logistic Manager, } \\
\text { R \& D manager, Head of } \\
\text { Production }\end{array}$ & $\begin{array}{l}\text { R \& D manager, Logistic } \\
\text { Manager, Shop floor } \\
\text { Manager }\end{array}$ \\
\hline Certification & $\begin{array}{l}\text { ISO } 14000 \\
\text { ISO } 18000\end{array}$ & $\begin{array}{l}\text { ISO/TS16949 } \\
\text { ISO14000 }\end{array}$ \\
\hline
\end{tabular}




\section{FIGURES}

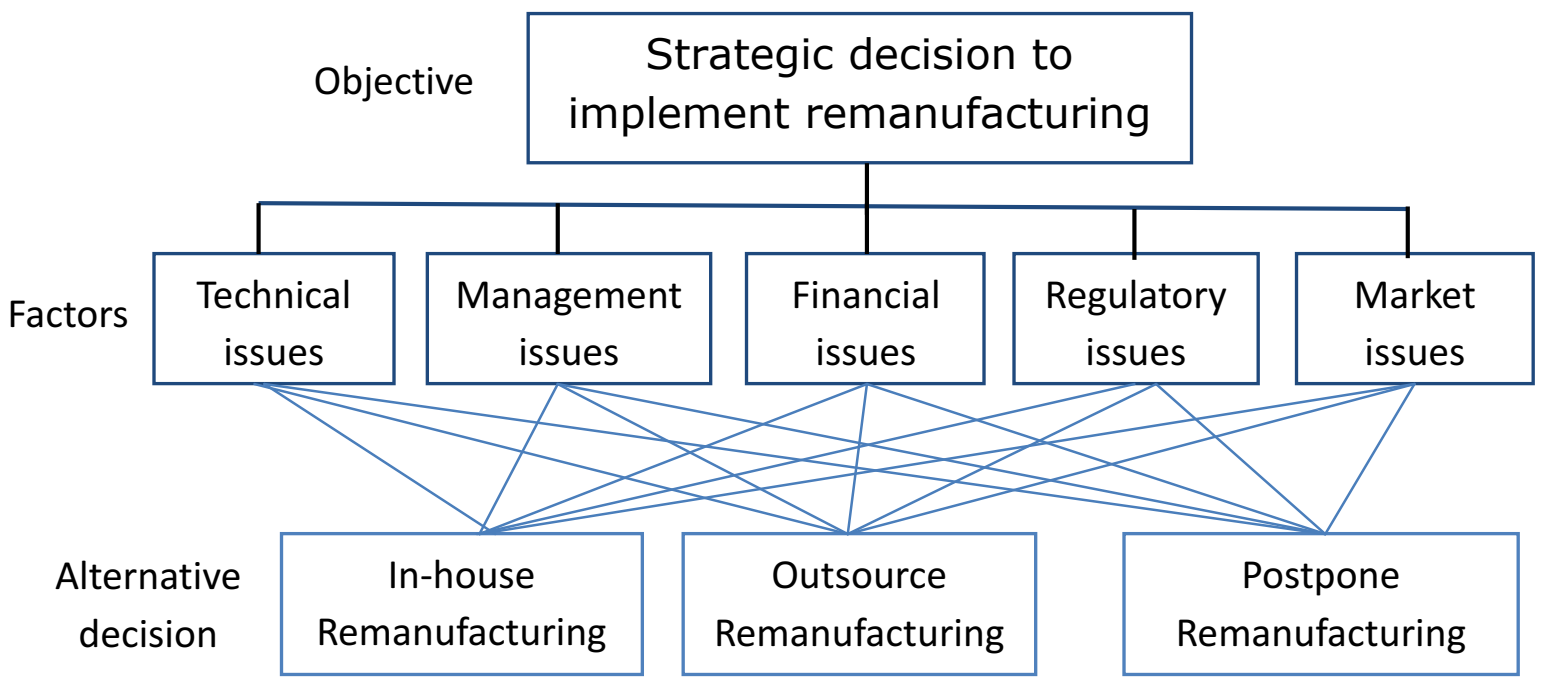

Figure 1: Strategic decision model for remanufacturing

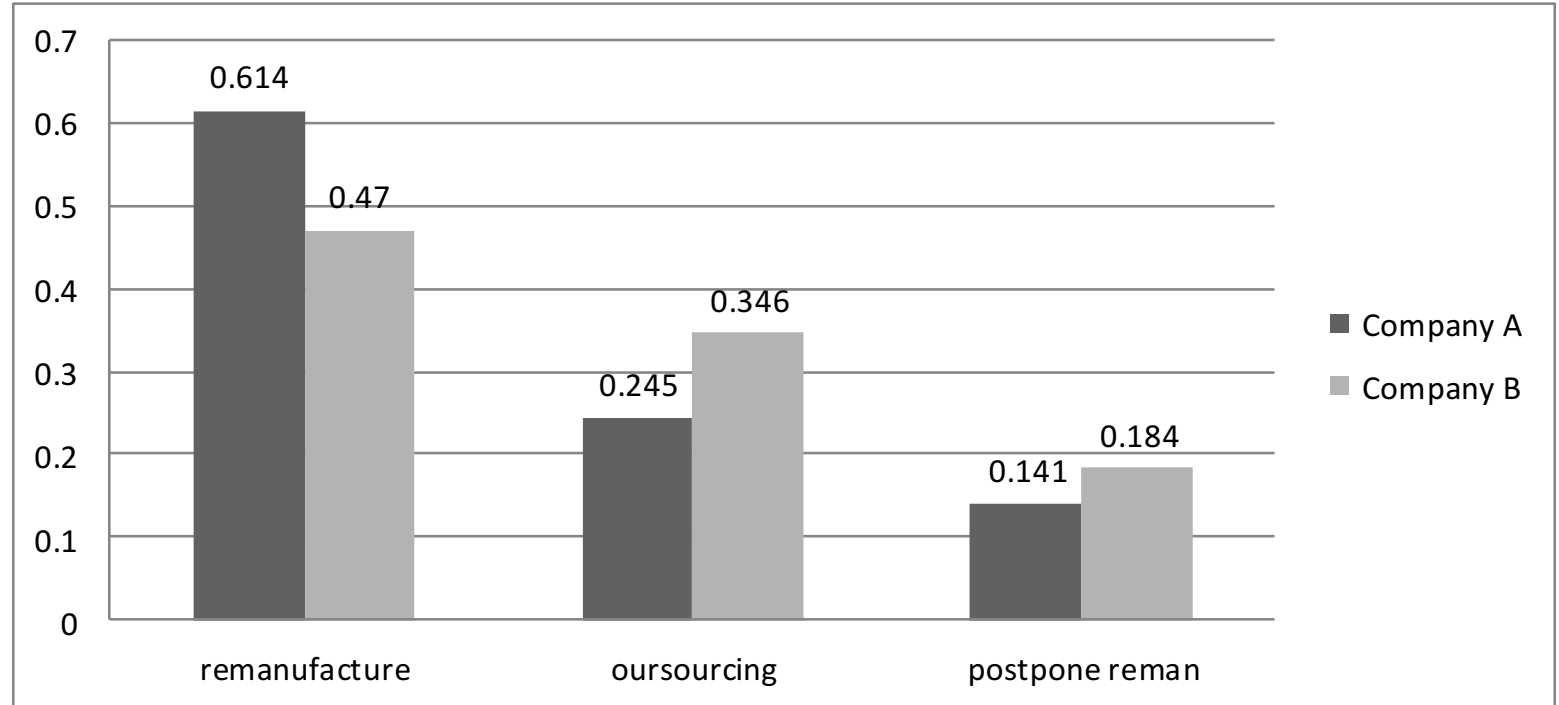

Figure 2: Comparative decision outcome 


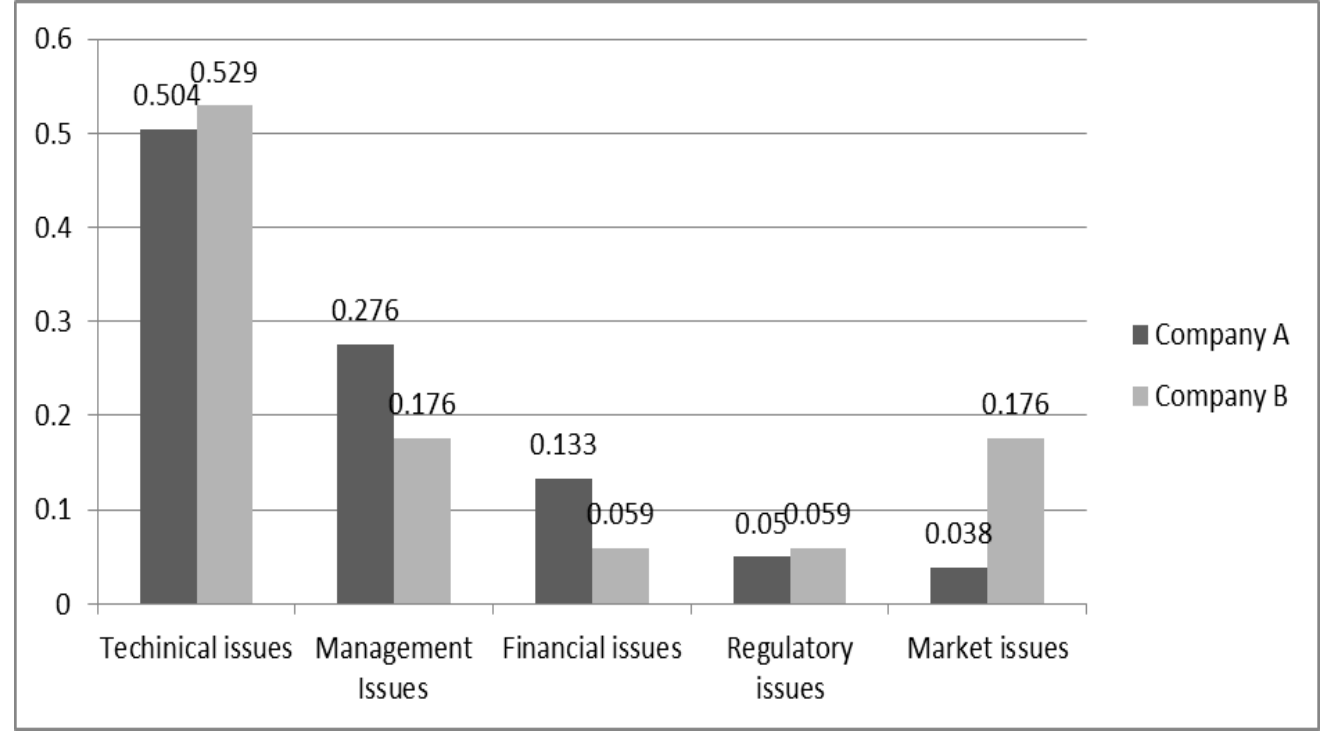

Figure 3: Relative importance of factors

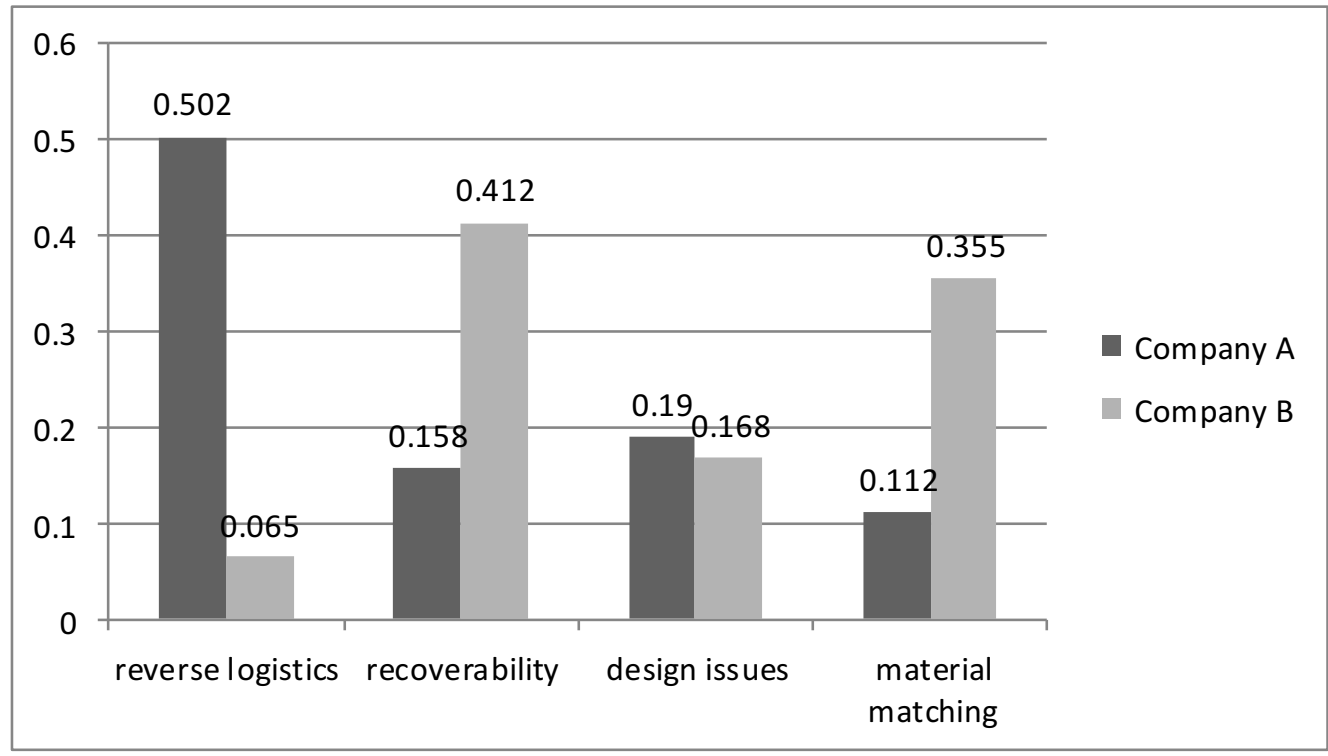

Figure 4: Technical factors comparison between companies 


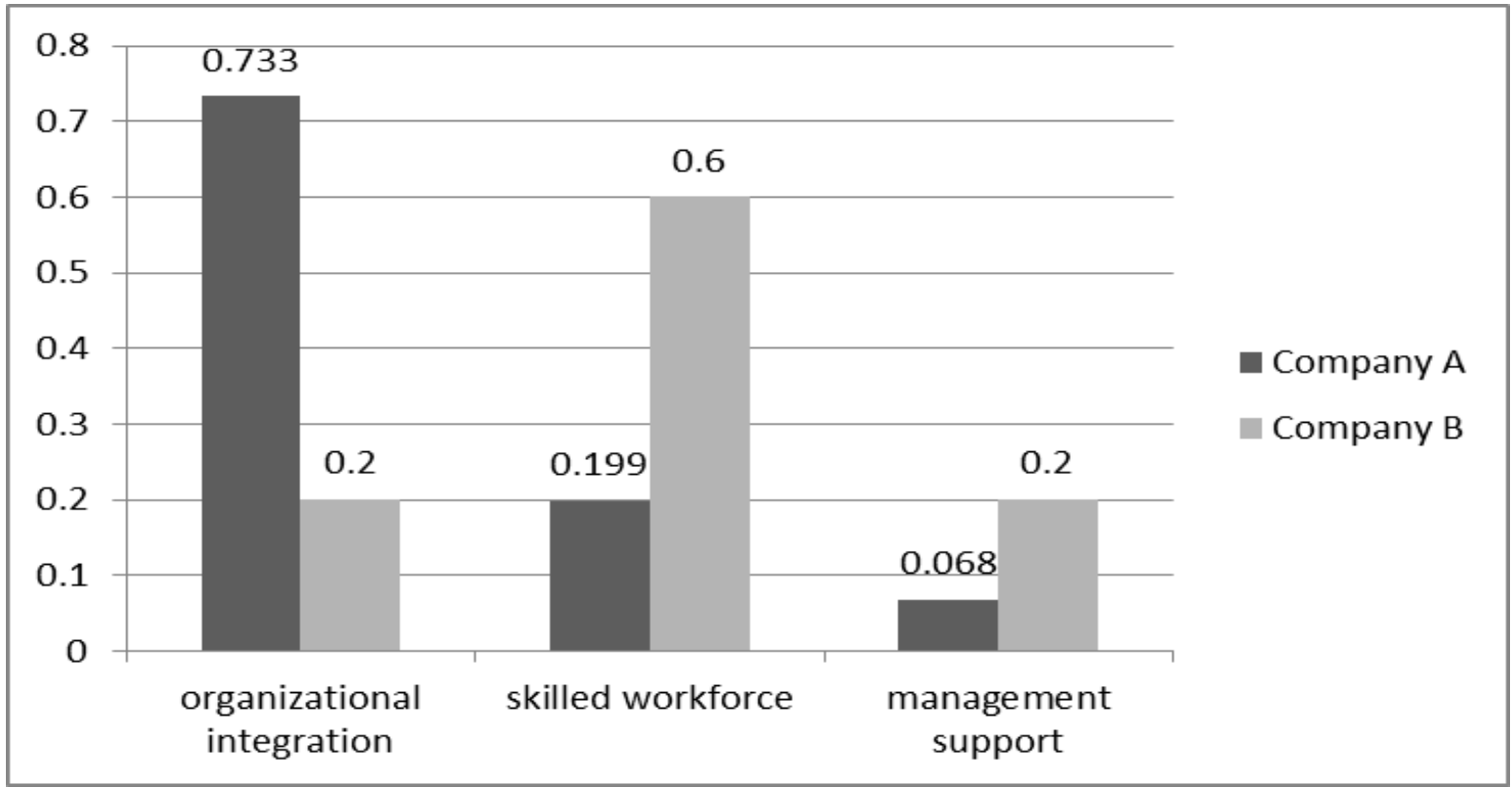

Figure 5: Management factors comparison between companies

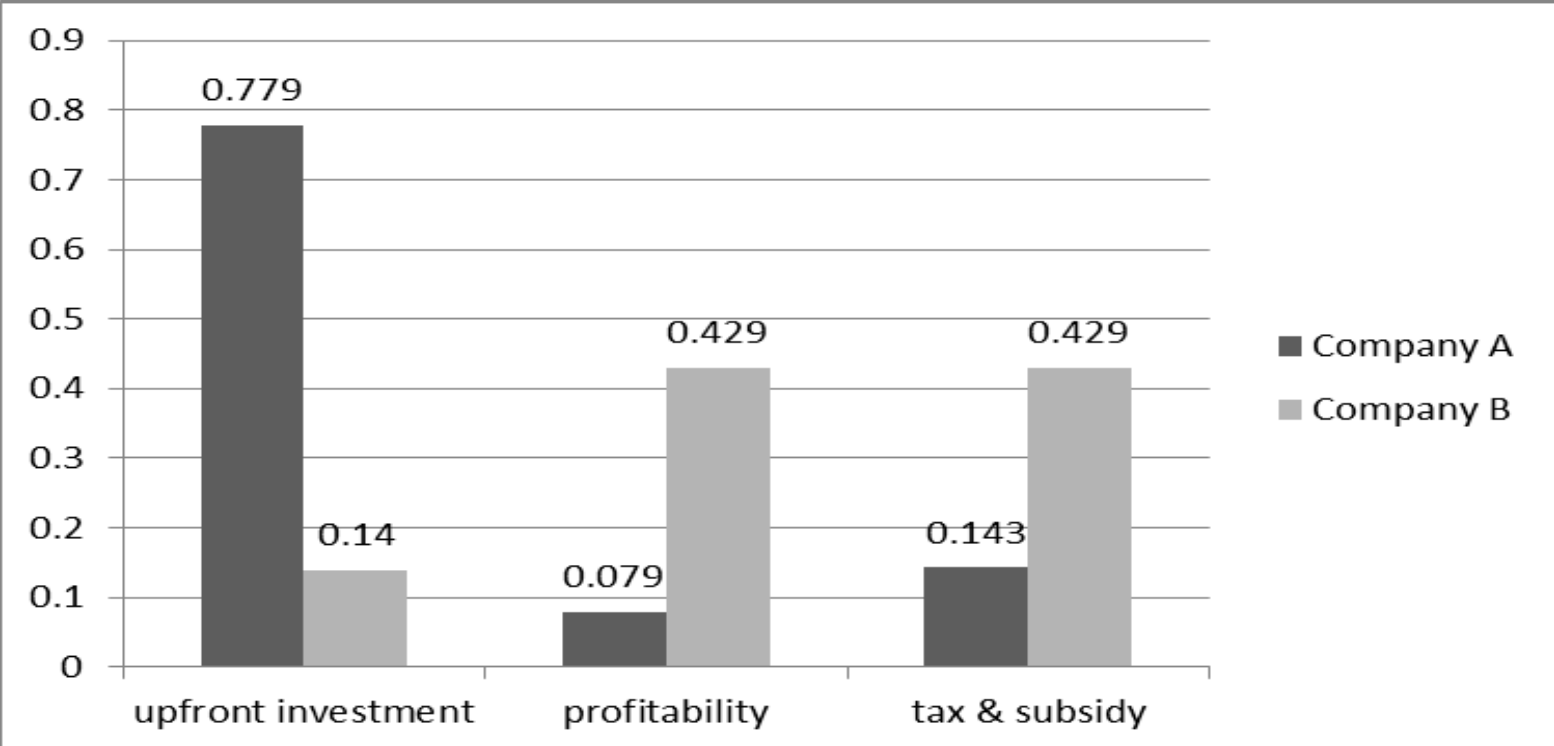

Figure 6: Financial factors comparison between companies 


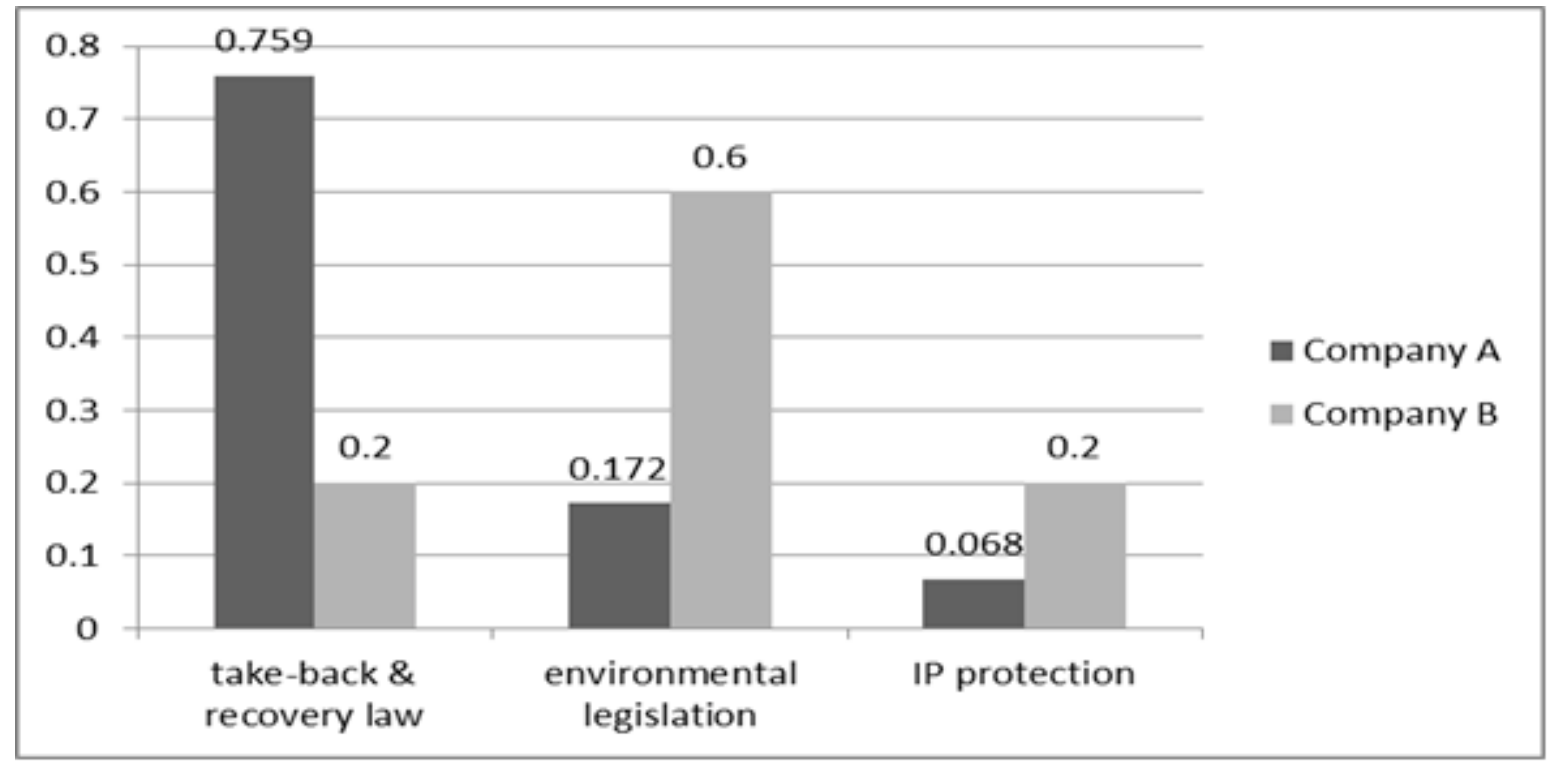

Figure 7: Regulatory factors comparison between companies

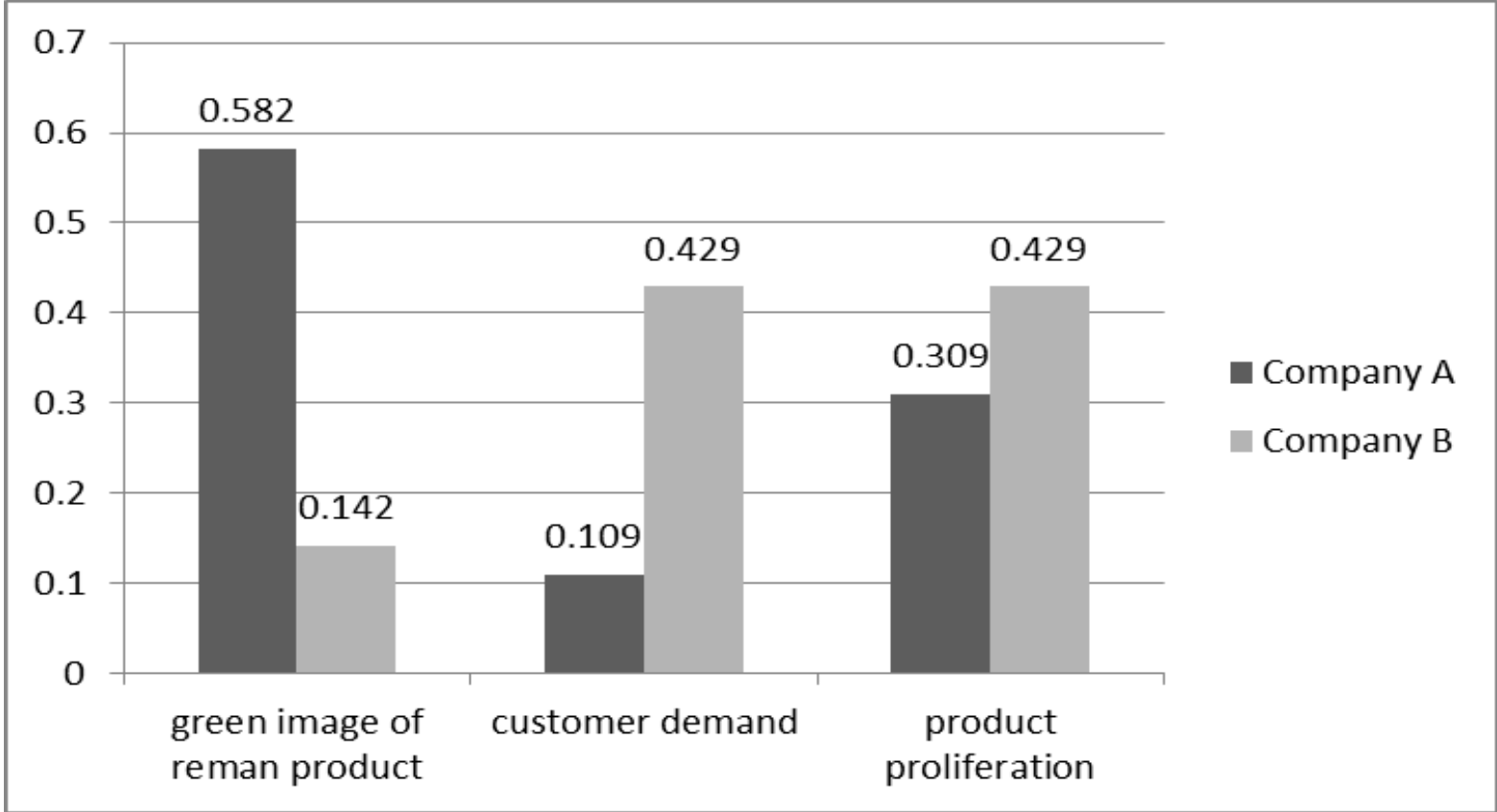

Figure 8: Market factors comparison between companies 